Winter 2016

\title{
Introduction: Global Human Rights Law and the Boundaries of Statehood
}

\section{Daniel Augenstein}

Tilburg Law School, D.H.Augenstein@uvt.nl

Hans Lindahl

Tilburg University, lindahl@uvt.nl

Follow this and additional works at: https://www.repository.law.indiana.edu/ijgls

Part of the Comparative and Foreign Law Commons, Human Rights Law Commons, and the International Law Commons

\section{Recommended Citation}

Augenstein, Daniel and Lindahl, Hans (2016) "Introduction: Global Human Rights Law and the Boundaries of Statehood," Indiana Journal of Global Legal Studies: Vol. 23 : Iss. 1 , Article 1.

Available at: https://www.repository.law.indiana.edu/ijgls/vol23/iss1/1

This Article is brought to you for free and open access by the Law School Journals at Digital Repository @ Maurer Law. It has been accepted for inclusion in Indiana Journal of Global Legal Studies by an authorized editor of Digital Repository @ Maurer Law. For more information, please contactrvaughan@indiana.edu.

\section{$\Psi$}

JEROME HALL LAW LIBRARY

INDIANA UNIVERSITY

Maurer School of Law
Bloomington 


\title{
Introduction: Global Human Rights Law and the Boundaries of Statehood
}

\author{
DANIEL AUGENSTEIN ${ }^{\star}$ AND HANS LINDAHL ${ }^{* *}$
}

\section{The Central Theme of the Special Issue}

Whatever the true historical origins and philosophical foundations of human rights-questions to which the contributors to this collection of essays give different answers-their protection has taken a distinctive form in the modern state legal order and, by extension, in the state-centered conception of international law. Arguing from a historical perspective, Samuel Moyn contends that, from American and French Declarations of the "Rights of Man" to the Universal Declaration of Human Rights, the main purpose of human rights was to organize and legitimize the social compact between the state and its citizens. ${ }^{1}$ If, in the course of the eighteenth century revolutions, the "rights of man" were proclaimed as universal principles to which positive law was supposed to conform, these rights "only appeared through the state, and there was no forum above it, or at times even in it, in which to indict the state's transgression." 2 Human rights retained their state-centered focus with their appearance on the international stage after World War II, now in the form of international declarations and covenants established by and for independent states endowed with sovereign equality and national collective self-determination. ${ }^{3}$ The global expansion of human rights in this period thus reaffirmed, rather than undermined, the central role of the state in their creation, interpretation, and enforcement. As Marti Koskenniemi says, "[b]y establishing and consenting to human rights limitations on their own

\footnotetext{
* Associate Professor, Tilburg Law School and Humboldt Senior Research Fellow, Wissenschaftszentrum Berlin. E-mail: D.H.Augenstein@uvt.nl.

** Professor of Legal Philosophy, Tilburg University and Research Fellow, Stellenbosch Institute for Advanced Study, Mostertsdrift, Stellenbosch, South Africa. Email: Lindahl@uvt.nl.

1. See generally Samuel Moyn, The Last Utopia: Human Rights in History (2010).

2. See $i d$. at 26.

3. See id. at 94-98 (detailing the post-war U.N. declarations and covenants that pertain to human rights and self-determination).
}

Indiana Journal of Global Legal Studies Vol. 23 \#1 (Winter 2016)

(C) Indiana University Maurer School of Law 
sovereignty, states actually define, delimit, and contain those rights, thereby domesticating their use and affirming the authority of the state as the source from which such rights spring." 4

From an analytical perspective, this state-centrism of human rights can be usefully captured by two sets of distinctions that structure their legal operation in the international order of states: that between the public and the private and that between the territorial and the extraterritorial. ${ }^{5}$ As regards the former, human rights law is traditionally seen as imposing duties on public state authorities to respect, protect, and fulfill the rights of private individuals. This reflects liberal concerns with preventing public state power from encroaching upon the private sphere of individual freedom. Yet it also entails that the legal protection of human rights in the relationship between private actors is ensured only indirectly via positive state obligations. As regards the latter distinction, an important consequence of the compartmentalization of human rights in the international order of states is that their legal protection is traditionally not thought to extend to everyone and everywhere, but is rather confined to the territorial state legal order. At least as a default rule, each state has a singular legal obligation and entitlement (to the exclusion of other states) to respect, protect, and fulfill the human rights of individuals located in its own territory.

One of the virtues of the recent "business and human rights" debate-reflected most prominently in the United Nations Guiding Principles on Business and Human Rights (UNGPs) endorsed by the U.N. Human Rights Council in June 2011-is that the debate has documented in considerable detail the significant impacts of global business operations on the protection of human rights in the international legal order of states. ${ }^{6}$ As John Ruggie, former Special Representative of the U.N. Secretary-General on Business and Human Rights and author of the UNGP, notes,

[t]he root cause of the business and human rights predicament today lies in the governance gaps created by globalization - between the scope and impact of economic forces and actors, and the capacity of societies to manage their adverse consequences. These

4. Martti Koskenniemi, The Future of Statehood, 32 HARV. INT'L L.J. 397, 406 (1991).

5. For a useful introduction, see generally OLIVIER DE SCHUTTER, INTERNATIONAL Human Rights LaW: CASES, MATERIALS, COMMENTARY (2010).

6. Special Representative of the Secretary-General, Guiding Principles on Business and Human Rights: Implementing the United Nations "Protect, Respect and Remedy" Framework, U.N. Doc. A/HRC/17/31 (Mar. 21, 2011) [hereinafter UNGPs]. 


\begin{abstract}
governance gaps provide the permissive environment for wrongful acts by companies of all kinds without adequate sanctioning or reparation. How to narrow and ultimately bridge the gaps in relation to human rights is our fundamental challenge. ${ }^{7}$
\end{abstract}

On the one hand, global business operations erode the legal and political authority that states wield over their territory, thus diminishing their ability to protect human rights within their own borders. On the other hand, global business operations amplify the human rights impacts of states' business-related laws and policies on individuals in other states, and enhance states' opportunities to use their "corporate nationals" to pursue foreign policy objectives. ${ }^{8}$ From both perspectives, the exposure of the international order of public and territorial states to the human rights impacts of private and global business operations threatens to undermine the normativity of international human rights law. At the same time, international law's state-centered heritage poses significant conceptual and practical challenges to legal reform, not least because the very distinctions between public and private, and between territorial and extraterritorial, are deeply embedded in the modern conception of statehood. In the context of the distinction between public and private, this is reflected in, for example, debates as to whether international law does or should directly impose human rights obligations on private corporations and thus treat them on par with public states. In the context of the distinction between the territorial and extraterritorial, a common concern with extraterritorial human rights protection is that it may unduly interfere with the sovereign rights that other states wield over their territory and the people therein. It is against this background that the contributions to this Special Issue examine how human rights responses to violations committed in the course of global business operations transform the boundaries of statehood constitutive of the state-centered conception of international human rights law. A guiding concern is to recover the public (and political) nature of human rights law under conditions of globalization.

7. Special Representative of the Secretary-General, Protect, Respect and Remedy: A Framework for Business and Human Rights, I 3, U.N. Doc. A/HRC/8/5 (Apr. 7, 2008).

8. These challenges are further elaborated in Daniel Augenstein, The Crisis of International Human Rights Law in the Global Market Economy, in 44 NETHERLANDS YEARBOOK INTERNATIONAL LAW 2013 41, 43 (Mielle K. Bulterman \& Willem J.M. van Genugten eds., 2014) ("[T]he exposure of the international legal order of states to the operations of global business entities leads to a collusion of sovereign state interest and globalised corporate power to the detriment of victims of human rights violations in the global market economy."). 


\section{CONTRIBUtions To THE SPECIAL ISSUE}

\section{A. The Boundaries of Human Rights Law}

Hans Kelsen reminds us that human rights law-like all forms of law-must answer four fundamental questions of legal ordering: who ought to do what, where, and when. The spatial and temporal boundaries of legal ordering entail that human rights law is valid only "in some space or another and for some time or another-in other words, that it refers to events that take place somewhere and at some time."9 In addition, we must specify the material boundaries of human rights law (the subject matter of its protection) and its personal boundaries that circumscribe the beneficiaries of such protection.

If the spatial, temporal, and subjective (material and personal) boundaries of human rights have traditionally been demarcated by the state legal order, globalization is often associated with a transformation of the space-time of modern social relations:

most contemporary social theorists endorse the view that globalization refers to fundamental changes in the spatial and temporal contours of social existence, according to which the significance of space or territory undergoes shifts in the face of a no less dramatic acceleration in the temporal structure of crucial forms of human activity. ${ }^{10}$

Against this background, the first three contributions to this Special Issue by Upendra Baxi, Fleur Johns, and Larry Catá-Backer examine the changing boundaries of human rights law under conditions of globalization.

Drawing attention to international law's past and present colonial pathways, Upendra Baxi discusses how the spatial demarcation of human rights in the international ("Westphalian") order of states contributes to the global production of "geographies of injustice."11 His analysis focuses on two aspects of the statist framing of contemporary conditions of "human rightlessness": private international law (PIL) as an extrapolation of "colonial capitalism" that remains partisan to the

9. Hans Kelsen, Introduction to the Problems of Legal Theory 12 (Bonnie Litschewski Paulson \& Stanley L. Paulson trans., Oxford Univ. Press 1992) (1934).

10. William Scheuerman, Globalization, STAN. EnCYClOPEDIA PHIL. (June 10, 2014), http://plato.stanford.edu/archives/sum2014/entries/globalization.

11. Upendra Baxi, Some Newly Emergent Geographies of Injustice: Boundaries and Borders in International Law, 23 IND. J. GLOBAL LEGAL STUD. 15, 25-26 (2016). 
interests of the Western "family of nations" and its multinational corporations; and "Third Worldism" as a state of consciousness and a form of social organization that remains derivative of, and therefore perpetuates, international law's colonial heritage. Baxi is overall skeptical about the prospects of liberating PIL from its statist doctrinal corset ("competence, comity, convenience"), however little the latter may correspond to the real places of the production and endurance of human rightlessness in a "global risk society." Against the derivative or "mimetic" understanding of Third Worldism, he emphasizes the "original" counterhegemonic nature of its ideology that is increasingly (re-)claimed by impoverished peoples in the global South and North alike to challenge imperialist and neocolonial readings of development, global governance, and human rights.

Fleur Johns examines the future of human rights in the changing relationship between the temporal authority of the state and the rhythms of global finance capital. ${ }^{12}$ The temporality of human rights is both parasitic on, and irreducible to, the composite times of states and markets. On the one hand, Johns sees human rights submerged into the temporal authorities of both. On the other hand, "[p]aradoxically, this fitful temporality of international human rights law may be less about confirming rightful time ... than a matter of insistently evoking the 'disjuncture of the unjust' through repeated alignments with, and disarticulations from, other temporal registers." 13 State-based law, both national and international, structures the temporality of human rights in the longue durée, as expressed in narratives of progress and development (from rights-infringing pasts to rights-respecting futures) or, more mundanely, in the "everyday" routine of office hours, meeting schedules, and periodical reviews of states' human rights performance by U.N. treaty bodies. If international human rights law occasionally allows for temporal dislocations (permitting derogations in a "state of emergency" or providing for measures to be taken "immediately" or "promptly"), late capitalism with its just-in-time preoccupations entails a more profound demise of the long-term that catapults human rights into the "real time" of events and happenings. It may thus appear that what rights-bearing subjects today hold in common is less a commitment to any singular measure of value over time than a shared sense of ad hoc temporal coincidence avant la crise. In what sense, Johns asks, "might a young, unskilled, unemployed person in the United States, a subsistence rice farmer in Laos, and an asylum seeker eking

12. Fleur Johns, The Temporal Rivalries of Human Rights, 23 IND. J. GLOBAL LEGAL STUD. 39, 40 (2016).

13. Id. at 41 (quoting JACQUeS DeRRIDA, SPECTERS of MARX: The STATe OF THE DeBT, THE WORK OF MOURNING, AND THE NEW INTERNATIONAL 22 (Peggy Kamuf trans., 1994)). 
out the days of a hunger strike in detention in Australia be understood to occupy the same time scale?" 14 Under these conditions, recovering the public and political nature of human rights becomes a matter of reactivating the times and rhythms of nationhood and the global economy as political questions of first order.

In his contribution, Larry Catá Backer focuses on the fate of the individual in human rights "governance regimes" within and beyond the state. ${ }^{15}$ His analysis centers on the problem of representation in the context of the global business and human rights debate. Who is being represented by claims to protect human rights raised in business and human rights fora (the individual as the object of representation)? Who can legitimately claim to speak on behalf of the individual as the subject of representation? Catá Backer describes a transformation of the organization of state power after the 1950s, in the course of which the individual rights-bearer became dissolved into a mass population represented as an aggregation of its group characteristics. In the "fractured territories" of global human rights governance, the individual is appropriated by the three "Estates General" reigning over the implementation of the UNGPs: states, business, and civil society organizations. Dwelling on the annual United Nations Forum on Business and Human Rights, he critiques the partial and self-serving nature of the representational claims raised by these estates for inhibiting the effective participation of individuals in a global assembly constituted for their protection. Moving back to the "abstracted terrain" of the state as the recipient of international norms, Catá Backer notes that the more intensely "the global structures of law focus on the state, the more profoundly the state disintegrates as a unitary site for law grounded in popular representation." 16 The extraterritorial application of domestic law, the transplantation of national standards of corporate responsibility through global supply chains, and the projection of global regulatory power administered by international civil society organizations onto the state legal order all contribute to a partition of state territory into distinct governance regimes whose representational logic operates beyond the reach of the state polity. Taken together, the fractured territories and abstracted terrains of human rights governance regimes suggest a transformation of the individual as the represented subject of human rights within and beyond the state.

14. Id. at 56.

15. Larry Catá Backer, Fractured Territories and Abstracted Terrains: Human Rights Governance Regimes Within and Beyond the State, 23 IND. J. GLOBAL LEGAL STUD. 61, 64 (2016).

16. Id. at 84 (omission of emphasis found in original). 


\section{B. Human Rights between Public and Private Power and Authority}

The contributions by Claire Cutler, Sheldon Leader, and David Bilchitz examine the ramifications of the changing parameters of the distinction between public and private for the transformation of statehood under conditions of globalization. As Leader notes, the shifting boundaries of statehood transform the rationality and legitimacy of the state by widening or shrinking the scope of its own powers and "var[ying] the division of labor between itself and bodies lying outside of it." 17

Along these lines, Claire Cutler looks at the transformation of the nature and operation of public and private authority in the context of the investor-state regime. ${ }^{18}$ Whereas, in the past, foreign investors had to rely on their home states to represent their interests in relation to the state hosting the investment, international investment treaties now endow them with legal rights to directly sue the host state in binding international arbitration. This denationalizes and delocalizes control over private foreign investment and also curtails host states' capacity to assert public authority over their own domestic policy space, including for the protection of human rights. Moreover, it suggests a transformation of international law from regulating matters of public concern between states to protecting the autonomy of private actors in conducting their global commercial affairs. At the same time, the very distinction between public international law, as associated with politics, and private international law, as associated with markets, works to depoliticize the entire realm of international commercial activity by obstructing an understanding of the public and political dimension of private economic activity. By way of response, Cutler examines how human rights have been relied upon to contest the operations of the investor-state regime, both in cases where host states have raised human rights defenses against breach of contract claims brought by investors and in cases where civil society organizations have attempted to intervene in arbitration proceedings as amici curiae. The evidence of success is rather meager, which may suggest that international arbitration does not provide an adequate forum to deal with matters of common public concern. Instead, host states' attempts to regain public authority and protect human rights in relation to foreign investors may be better served in international human rights courts.

17. Sheldon Leader, Statehood, Power, and the New Face of Consent, 23 IND. J. GLOBAL LEGAL STUD. 127, 127-28 (2016).

18. A. Claire Cutler, Transformations in Statehood, the Investor-State Regime, and the New Constitutionalism, 23 IND. J. GLOBAL LEGAL STUD. 95, 95-96 (2016). 
For Sheldon Leader, the transformation of statehood under conditions of globalization forces us to move beyond mere comparisons of public and private power, and instead toward new methods to legitimize power per se-be they found in the state or in civil society. ${ }^{19}$ Drawing on the social contract tradition, he grounds the rationale and legitimacy of power in the "fundamental value" of consent. The shifting boundaries of statehood are illustrated with the help of two different conceptions of consent: a restricted conception in which the protection of certain fundamental interests, including human rights, is a precondition for individuals to leave the state of nature and submit to the social order; and an extended conception that binds individuals to institutions in a purely instrumental way, which fails to ensure a baseline of protection against abuses of power by these very institutions. It is this latter conception of consent, legitimating renunciation of basic rights, that has begun to hold sway over the private and public domains of the social order. Drawing on examples from domestic labor law, Leader shows how individuals are induced to "gamble" with fundamental parts of their future by embracing a radically larger field of risk than contemplated under the restricted-consent conception, such as when they agree to give up their right not to be unfairly dismissed in exchange for shares in the company. At the international level, states themselves renounce with increasing frequency baseline protections of individual interests, be it by disenfranchising parts of their territory as international trading zones in which employment rights do not apply, or by contractually binding themselves to provide stable long-term conditions for foreign investors to the detriment of protecting the human rights of their own population..$^{20}$ If these examples suggest a trend towards relinquishing the principle that there are certain things individuals, and states on their behalf, cannot consent to, Leader concludes with a plea for reinstating a conception of restricted consent that vouches for the protection of human rights against abuses of power in the public as well as in the private domain.

David Bilchitz takes the global shift from public to private power as a starting point for arguing that multinational corporations (should) incur direct human rights obligations under public international law. ${ }^{21}$ Like Leader, Bilchitz draws on the social contract tradition to show that human rights protect fundamental interests of individuals whose

19. See Leader, supra note 17 , at $127-28$.

20. The latter mode of renunciation is discussed in more detail in Cutler, supra note 18 , at 95, 96-99.

21. David Bilchitz, Corporations and the Limits of State-Based Models for Protecting Fundamental Rights in International Law, 23 IND. J. GLOBAL LEGAL STUD. 143, 144-45 (2016). 
recognition by the state is part of their reason for accepting state authority in the first place. Human rights are "pre-existing" moral rights to which states seek to give effect in national-constitutional and international law. This allows him to put the individual as bearer of human rights entitlements (rather than the assignment of human rights duties to institutions) at center stage, challenging the notion that the state should be seen as the "originator" of human rights obligations, including those of non-state actors. Bilchitz offers a number of reasons why, under conditions of globalization, the protection of fundamental individual interests is badly served by confining human rights obligations to the international order of states. He considers and rejects two attempts to shift the boundaries between public and private to enhance state accountability for human rights violations committed by multinational corporations: an "indirect duty model" that imposes positive obligations on public authorities to protect the human rights of individuals against private corporate power; and an "expanded state model" that treats private corporations exercising public functions as part of the state for the purpose of allocating human rights obligations. Rather, Bilchitz contends that corporations themselves should be seen as "partially public" entities created not only as vehicles for private entrepreneurship and individual wealth maximization but also as agents of society endowed with responsibilities to the public good. This, finally, justifies treating multinational corporations as direct bearers of international human rights obligations, commensurate with their role as public agents of society.

\section{The U.N. Guiding Principles on Business and Human Rights}

The U.N. Guiding Principles on Business and Human Rights feature in many contributions to this Special Issue, but they receive most detailed attention in the essays by Radu Mares and Hans Lindahl. The UNGPs puts forward a "protect, respect, and remedy" framework of complementary and interlocking human rights duties and responsibilities of states and corporations structured around three pillars: the state duty to protect human rights against infringements by corporations through appropriate policies, regulation, adjudication, and enforcement measures; the corporate responsibility to respect human rights, meaning to act with due diligence to avoid infringing on the rights of others; and greater access by victims to effective remedies, both judicial and non-judicial, for corporate-related human rights violations. ${ }^{22}$ Following the endorsement of the UNGPs by the U.N.

22. UNGPs, supra note 6. 
Human Rights Council in 2011, a U.N. working group was established to further promote their effective and comprehensive dissemination and implementation. ${ }^{23}$

Radu Mares conceives of the UNGPs as part of a broader agenda to develop a new transnational and "multichannel" regulatory approach to business and human rights that moves beyond the old dichotomy between territorial human rights government (associated with international human rights law) and global human rights governance (associated with corporate social responsibility). ${ }^{24}$ Here, the transformation of the boundaries of statehood is not linked to an imposition of public human rights obligations on corporations in international law. ${ }^{25}$ Rather, it proceeds through a decentering of human rights from the international order of states that ensures the mutually supportive role of different "state-state" and "infra-firm" channels in protecting human rights across national-territorial borders. As Mares sees it, the UNPGs aims at "mobilizing new sources of public and private authority [to create] a new regulatory dynamic that augments the traditional state-centered and territory-based protection of human rights with the leverage brought by international economic interdependencies and multinational enterprises." 26 Two elements are crucial for the success of this global regulatory agenda: first, a "rootcause orientation" that, in addition to redressing corporate human rights "abuses" through domestic tort and criminal law, ensures the global responsibility of core companies in (Western) home states for their own conduct that produces effects throughout the global value chain, as well as for the conduct of their affiliates (whether subsidiaries or contractors) in the host states of corporate investment; second, a proper alignment of these "infra-firm channels" to ensure corporate respect for human rights with the more traditional but suitably adjusted "state-state channels" (international trade and investment law, international human rights law, and development aid). The ensuing "polycentric" governance approach, Mares notes, poses a challenge to the hegemonic role of the state in international law as much as it presents new opportunities for law to reassert itself in the global protection of human rights.

23. Human Rights Council Res. 17/4, Human Rights and Transnational Corporations and Other Business Enterprises, 17th Sess., May 30, 2015-June 17, 2011, U.N. GAOR, Supp. No. 53, A/17/4, I 6(a) (June 16, 2011). For a discussion of the proceedings of the U.N. Working Group on Business and Human Rights, see Backer, supra note 15, at 74-75.

24. Radu Mares, Decentering Human Rights from the International Order of States: The Alignment and Interaction of Transnational Policy Channels, 23 IND. J. GLOBAL LEGAL STUD. 171, 171 (2016).

25. As suggested by Bilchitz, supra note 21 at 143-170.

26. Mares, supra note 24 at 174 . 
In the latter vein, Hans Lindahl takes issue with the UNGPs' distinction between the state duty to protect human rights derived from international law (the first pillar) and the legally non-binding corporate responsibility to respect human rights rooted in a global "social license to operate" (the second pillar). ${ }^{27}$ While Lindahl, like Mares, is critical of confining public legal human rights obligations to states, his critique is directed against the state-based distinction between law and non-law on which this confinement is premised. He notes that the UNGPs' separation of the second pillar from the first, and, within the second pillar, the separation of corporations' duties to comply with domestic law from their global social responsibilities, entrenches the very statecentric approach to human rights they aim to overcome. Lindahl views the corporate responsibility to respect human rights as an expression of legal ordering in the form of authoritative collective action. One problem with grounding corporate respect for human rights in a global social license to operate is that such license must be granted by a bounded social group as a plural political subject. To say that corporations are "authorized" to act as specialized organs of society is to view business operations "as part and parcel of what we, the social group, are doing together with a view to realizing the normative point of our joint action."28 Whether for the purposes of "public" human rights government or "private" human rights governance, this authorization is a public and political act through which a legal collective rules itself. This enables Lindahl to show that multinational corporations are legal orders in their own right, irreducible to the state legal orders in and across which they operate. Moreover, it explains how corporations, as legal subjects on par with states, can incur obligations to comply with international human rights law.

\section{Human Rights and Global Public Goods}

Lindahl's analysis suggests that one of the challenges to business and human rights is that whereas both "public" human rights government and "private" human rights governance are conditioned by "a determinate common or public good," it is precisely this notion of

27. Hans Lindahl, One Pillar: Legal Authority and a Social License to Operate in a Global Context, 23 IND. J. GLOBAL LEGAL STUD. 201, 202-203 (2016). See also UNGPs, supra note 6, at 13 ("The [corporate] responsibility to respect human rights is a global standard of expected conduct for all business enterprises wherever they operate. It exists independently of States' abilities and/or willingness to fulfil their own human rights obligations, and does not diminish those obligations. And it exists over and above compliance with national laws and regulations protecting human rights.").

28. Lindahl, supra note 27 , at 218 . 
common publicness that comes under pressure as global ordering is increasingly left to private actors and market forces favoring particular interests. $^{29}$ The final two contributions take up this challenge by examining the relationship between public goods and human rights in addressing matters of common global concern.

Daniel Augenstein disentangles the notions of public goods and human rights to "shed some critical light on their respective potential to attend to contemporary problems of globalization." 30 If economic decisions concerning public goods are but an expression of the public good (as the good that all members of a political community hold in common), the internal relationship between democratic self-legislation and human rights explains why the latter play a constitutive role in its political definition. The different ways in which public goods and human rights relate to the public good, traditionally vested in the nation-state, translate into distinctive challenges to their capacity to address matters of common global concern. On the one hand, the globalization of public goods is marked by their functional differentiation geared towards the realization of particular interests that will often act at cross-purposes with each other. On the other hand, the confinement of the internal relationship between human rights and democratic self-legislation to the territorial state legal order fails to account for the global human rights impacts of state-based decisions concerning public goods. According to Augenstein, the functional differentiation of global public goods and the territorial compartmentalization of universal human rights illustrate an important shortcoming of appeals to global justice that posit interests and values "we all" hold in common: they tend to conceal or evade political conflicts about their proper interpretation and implementation. The public-goods approach has responded to this problem by extending the scope of political jurisdiction over public goods to encompass all those "affected" by their costs and benefits. In the context of human rights, this finds a counterpart in attempts to account legally for the global human rights impacts of public goods through extending human rights jurisdiction beyond state territory. While both approaches come with problems of their own, taken together they may be indicative of a "horizontal" transformation of statehood under conditions of globalization that aims at recovering the public good beyond the international order of states.

Neil Walker's contribution begins where Augenstein's leaves off, asking whether the combination of public goods and human rights may, beyond mere complementarity, provide a "general answer to the

29. See id. at 220-21.

30. Daniel Augenstein, To Whom it May Concern: International Human Rights Law and Global Public Goods, 23 IND. J. Global LeGAL STUD. 225, 226 (2016). 
challenge of how to work out and operationalize [a] global ethics of collective responsibility." 31 Both concepts operate in a presumptively universal register, which makes them prime candidates for any broader project of global justice. Moreover, when combined, the focus of public goods on collective provision and the focus of human rights on individual well-being bring to the fore a core concern of modern political morality: the relationship between social obligations and individual freedom. Walker sets out by considering three approaches to global justice, associated with three different (but not mutually exclusive) models of global connectedness: a "concurrent interest" model that sees global interdependencies as providing purely instrumental reasons for collective action; a "mutual responsibility" model that emphasizes the historical causes of, and associated responsibilities for, the uneven distribution of wealth and well-being across the globe; and a "common concern" model that envisages a deeper set of mutual commitments and obligations grounded in our shared humanity. If the public-goods approach most closely resembles the first model, this suggests the modesty of its ambitions at the level of global political morality. Yet it is precisely this modesty that makes most apparent the lacuna of global political authority that could draw on a sufficiently developed transnational public and political engagement to give rise to a more embedded sense of global connectedness. If the human-rights approach, in turn, most closely resembles the third model, its view of political authority remains largely predicated on the nation-state, which inhibits its broader ambitions at the level of global political morality. This, Walker adds, also applies with regard to the extraterritorial application of human rights obligations discussed by Augenstein, insofar as these remain "an external source of instruction and exhortation to states to modify their actions, rather than a signal of the emergence of regional or global political communities with their own state-independent authoritative foundations." 32 In the end, both approaches confront us with the frustrating phenomenon of "one hand clapping": the publicgoods approach suffers from a deficit of global political authority, which reinforces its incompleteness at the level of political morality; the human-rights approach, in turn, remains predicated on state-centered structures of political authority, which translates into an unduly abstract discourse of universal moral entitlement that fails to spell out a conception of the public good sufficiently sensitive to justice at the global level.

31. Neil Walker, Human Rights and Global Public Goods: The Sound of One Hand Clapping?, 23 IND. J. GLOBAL LEGAL STUD. 249, 250 (2016) (emphasis in original).

32. Id. at 262 (emphasis in original). 


\section{ACKNOWLEDGMENTS}

The contributions collected in this Special Issue are the outcome of a colloquium on "Global Human Rights Law and the Boundaries of Statehood" held at the Stellenbosch Institute for Advanced Study (STIAS) in South Africa in March 2015. The colloquium is the first in a series of topics to be addressed within the STIAS research project, "Boundaries and Legal Authority in a Global Context," coordinated by Hans Lindahl and Louise du Toit. We would like to express our gratitude to STIAS for the funding and logistics of the colloquium. Our particular thanks are due to the director of STIAS, Hendrik Geyer, for hosting our colloquium, and to Nel-Mari Loock and Maria Mouton for their friendly and diligent assistance with its organization. Daniel Augenstein has conducted much of the work in preparation of this Special Issue during a research leave at the Wissenschaftszentrum Berlin funded by the German Humboldt Foundation, whose support he gratefully acknowledges. Last but not least, we would like to thank the editors of the Indiana Journal of Global Legal Studies for their commitment and editorial assistance in seeing this collective research project through to publication. 